
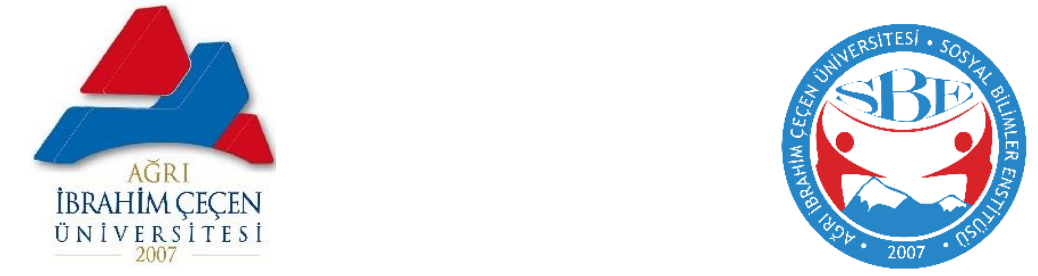

\title{
DOĞA VE KAMP TURIZMİ: AĞRI BALIK GÖLÜ ÖRNEĞİ
}

Nature and Camp Tourism: Example of Ağm Fish Lake

\section{Barıs KARAMIZRAK}

Cumhuriyet Üniversitesi, Sosyal Bilimler Enstitüsü, Doktora Öğrencisi,

$$
\text { b.karamizrak5@gmail.com }
$$

iD https://orcid.org/0000-0002-6804-9500

Ağrı ibrahim Çeçen Üniversitesi Sosyal Bilimler Enstitüsü DergisiJournal of Ağrı ibrahim Çeçen University Social Sciences InstituteAïCUSBED 6/2 Ekim / October 2020 / Ağrı

ISSN: 2149-3006

e-ISSN: $2149-4053$

\begin{tabular}{|l|l|}
\hline Makale Türü-ArticleTypes: & Araştırma Makalesi \\
\hline Geliş Tarihi-ReceivedDate: & 27.07 .2020 \\
\hline Kabul Tarihi-AcceptedDate: & 18.09 .2020 \\
\hline Sayfa-Pages:: 311-327 & \multicolumn{1}{|c|}{ https://doi.org/10.31463/aicusbed.774566 } \\
\hline
\end{tabular}

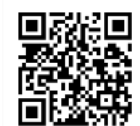

http://dergipark.gov.tr/aicusbed

Thisarticlewascheckedby

$\checkmark$ iThenticate 



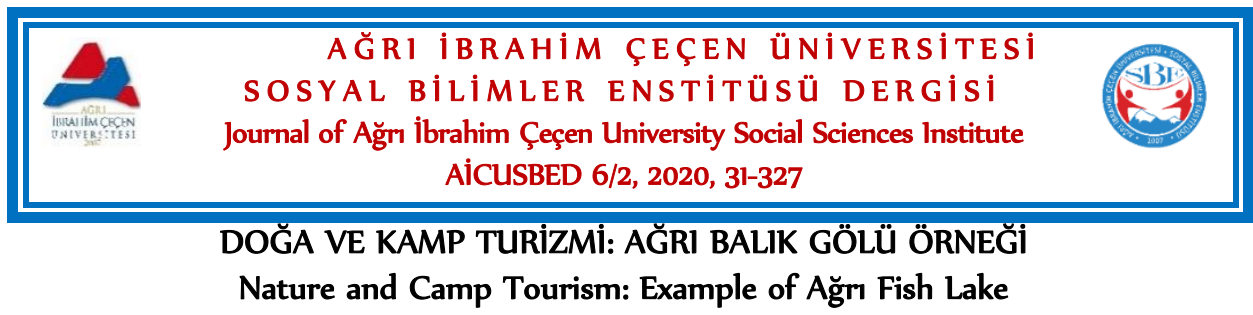

Öz

Barı̧̧ KARAMIZRAK

Tüketici eğilimlerinde sürekli değişim yaşandığı modern zamanlarda alternatif turizm faaliyetleri de önem kazanmaktadır. Son yıllar da tüketici eğilimlerinin çok fazla değiş̧mesi sonucunda doğa ve kamp turizmi önemini gittikçe artıran bir turizm faaliyeti olarak ön plana çıkmaktadır. Türkiye çeşitli doğa güzellikleri, gölleri, denizleri ve ormanlarıly doğa ve kamp turizmi için önemli merkezlerden birisidir. Özellikle üniversite çağındaki gençlerin daha ekonomik olması dolayısıyla doğa ve kamp turizmini tercih ettiği görülmektedir.

Ağrı ili çeşitli turizm faaliyetlerine, tarihi ve kültürel çeşitliliğe sahip olmasına rağmen sosyo-ekonomik yönden ele alındığında Türkiye'nin en geride kalmış illerinden birisidir. Ekonomik yönden kıt kaynaklara sahip bu ilimiz için turizm, hayati derecede önemli bir konumda bulunmaktadır. Balık gölü de Ağrı'nın en önemli turizm değerlerinden birisi olarak bu yönde değerlendirildiği takdirde sadece il ekonomisine değil ülke ekonomisine de katkı sağlama gücüne sahip bir potansiyeldir.

Bu çalışmada doğa ve kamp turizmini, Balık Gölünün turizm potansiyelini, balık gölünün il ekonomisine katkısını, Balık Gölünde hangi çalışmalar yapılırsa turizm yönünden daha etkin bir konuma getirilebileceği ve Balık Gölünün mevcut eksiklikleri tespit edilerek çözüm önerileri sunmayı amaçlamaktadır.

Anahtar Kelimeler: Doğa ve Kamp Turizmi, Ağrı turizm, Balı Gölü

\begin{abstract}
In modern times when consumer trends are constantly changing, alternative tourism activities are also gaining importance. As a result of the change in consumer trends in recent years, nature and camping tourism has come to the fore as a tourism activity that is increasing its importance. Turkey diverse natural beauty, lakes, seas and is one of the major centers for tourism with nature and the forest camp. It is observed that especially university students prefer nature and camping tourism because it is more economical.

Agri province on various tourism activities, when historical and cultural diversity of ownership, despite the socio-economic aspects are taken from one of Turkey's most backward province. Tourism has a vitally important position for this city, which has economically viable resources. Fish lake is also a potential that has the power to contribute not only to the economy of the province but also to the economy of the country, if it is evaluated as one of the most important tourism values of Ağrı.

In this study, nature and camping tourism, the tourism potential of Fish Lake, the contribution of the fish lake to the economy of the province, whatever studies are carried out in Fish Lake can be made more effective in terms of tourism, and the current deficiencies of Fish Lake are determined and offer solutions.
\end{abstract}

Keywords: Nature and Camping Tourism, Ağrı tourism, Fish Lake 


\section{Giriş}

Gün geçtikçe etkisini artıran turizm faaliyetleri önemli bir ekonomik gelir haline dönüşmektedir. Bacasız fabrika olarak adlandırılan turizm faaliyetleri ülkelere döviz girişini sağlamaktadır. Ekonomik dengenin önemli unsurlarından birisi de istihdamdır. Turizm, istihdamı artırıcı özelliğinin fazla olması sebebiyle ekonomik dengelerin düzenli seyrine yardımcı olmaktadır. Gelişmekte olan ülkeler için turizmden elde edilen gelir özellikle ülkenin cari açığı kapatmada önemli görev üstlenmektedir. Bu yüzden bazı ülkeler için turizm gelirleri hayati derecede önemli bir konumdadır. Türkiye de gelişmekte olan ülke konumunda olması sebebiyle turizm gelirleri ekonomik denge yönünden önemli bir konumda yer almaktadır.

Günümüzde etkisini artıran turizm faaliyetlerinin başında doğa ve kamp turizmi gelmektedir. Ülkemizde üniversite öğrenci sayısının ve üniversiteli gençlerin gezip görme isteklerinin artması sonucu çadır kampına olan talep gün geçtikçe artış göstermektedir. Özellikle çadır kampını öğrencilerin tercih etme oranı yüksek bir seviyededir. Bunun sebebi ise ekonomik olması dolayısıyla öğrenciler bu turizm faaliyetini daha çok tercih etmektedir.

Balık gölü de özellikle çadır kampı ve yükseltisi yönünden avantajlı olması dolayısıyla spor kamp merkezleri için önemli bir avantajı elinde bulundurmaktadır. Özellikle Hollanda ve Avusturya yükselti yönünden avantajları nedeniyle sporcu kamp merkezlerinin başında gelmektedir ve bunu ekonomik avantaja çevirerek önemli miktarda döviz girdisi sağlayabilmektedir. Balık Gölü de hem yükseltisi hem doğal güzelleri hem de spor kamp turizmi yönünden değerlendirildiğinde sadece ülkemiz de değil diğer ülkelerin de burayı tercih etmesi sağlanabilir.

\section{Turizm}

Önemli ekonomik faaliyet alanlarından biri olan turizm faaliyetleri; bölgelerin coğrafi yapılarına göre çeşitlilik göstermektedir. İnsanların sürekli yaşadıkları yerlerden farklı yerlere günübirlik şekilde ya da daha uzun süreli konaklama yapmak için veya dinlenme, gezip keşfetme yeni kültürleri tanıma dışında ayrıca eğitim ve sağlık imkânlarından faydalanmak gibi isteklerinden doğan turizm hareketleri, günümüzde ulusal gelirin artmas1 noktasında, ulaşım ve iletişim araçlarının git gide gelişmesiyle birlikte daha da ilerleme kaydetmiş̧ir (Doğan,2011:90). Geçmişte dağlar ve ormanlık alanlara öteden beri ulaşılamama ya da zor ulaşımdan dolayı insanların daha çok kullanmasına engel olmuş, antik çağlarda ise insanları güvenlik nedeniyle kendisine çekmiş, günümüz de ise dünya da ki milyonlara yakın insanı farklı ideallerle kendine

http://dergipark.gov.tr/aicusbed 6/2 Ekim/ October 2020 
çekmeye devam ettiği görülmektedir. Yakın bir zamana kadar coğrafyacıların, hem dünyada ve hem de ülkemizde fiziki ve beşeri yönden dağlarla ilintili olarak çok sayıda araştırmalar yapılmış ve bunları yayımlamışlardır (Somuncu, 2004:2-5).

Turizm en önemli dinamiklerinden biri tüketici olduğundan dolayı son zamanlarda değişimleri öngören, mevcut kaynak değerlerini en etkin ve verimli biçimde kullanan, turistin doğal ve kültürel çevreye herhangi bir zarar vermeden memnun bir şekilde ayrılmasına imkân sağlayan ve sürdürülebilirlik yönünden farkındalık yaratan turizm planlaması yaklaşımı ön plana çıkmasını sağlamaktadır (Kurt Konakoğlu, 2018: 8).

\section{Doğa Ve Kamp Turizmi}

21.yüzyılda her yıl milyonlarca insan olağan yaşamlarını geçirdikleri yerlerden geçici bir süre ayrılarak başka yerlere seyahat etmekte ve buralarda eğlenme, gezip görme, dinlenme ve öğrenme gibi sosyal ve kültürel sebeplerle seyahat edip konaklama yapmaktadırlar. Turizm olarak görülen bu olay, ekonomik ve sosyal yönden de geniş etkiler ortaya çıkararak günümüz dünyasının belirleyici bir özelliğini oluşturmaktadır (Barutçugil, 1986: 1). Turizm, ulaştığı alanlarla birlikte sanayileşmenin yanında uluslararası ticaret gibi önemli bir alan olma özelliğine kavuşmuştur. Hizmet endüstrisi olarak da isimlendirilen turizm; ulusal ve uluslararası alanda kazandığı imajla ile birlikte yatırımları, iş hacmini büyüten, gelir oluşmasını sağlayan, döviz ve istihdam sağlayan, sosyal ve kültürel hayatı etkileyen,çevreyi koruyan bir kapsam haline gelmiştir (Usta, 2016: 2). Turizm bir toplumun yaşam kalitesini artırarak, yeni iş olanakları sağlayarak, insanların toplum bilincinin oluşmasını sağlayarak ve sosyo- kültürel anlamda değişimleri de beraberinde getirerek önemli bir rol oynadığı görülmektedir (Güzel, 2013: 782).

Türkiye doğal güzelliklerinin yanı sıra; güneşi ve iklimi ile kamp turizmi için çok ideal bir potansiyel barındırmaktadır. Ülkemiz, kamp turizmi açısından değerlendirildiğinde yerli ve yabancı kampçıların beklentilerini kolaylıkla karşılayabilecek niteliklere sahip olmasının yanı sıra ziyaretçilere doğa ile iç içe, ekonomik ve daha kaliteli bir tatil geçirme imkânı da sağlamaktadır (Doğantan, 2014: 16). Türkiye'de genellikle kampçılık organizasyonlarında en çok tercih edilen 10 il şunlardır; İzmir, Muğla, Denizli, Balıkesir, Bursa, Trabzon, Tekirdağ, Rize, Artvin ve Gümüşhane'dir (Her Mevsim Karadeniz Projesi Master Planı, 2013: 256). Ağrı Balık Gölü de değerlendirildiği takdirde altyapı ve tesis gibi eksiklikleri giderildiğinde bu illerin arasına girebilecek kapasiteye sahip olduğu görülmektedir.

http://dergipark.gov.tr/aicusbed 6/2Ekim/October 2020 
Günümüzde kamp, öncelikle bir eğlence aktivitesi olmasının yanı sıra insanların doğada geçici olarak zaman geçirdiği bir tür aktivitedir. Kamp, doğanın bozulmamış yapısını keşfetme olanağı sunmaktadır. Kampçılar avcılık, balık avlama, bitki çalışması, yüzme, kuş ve yaban hayatı gözlemciliği ve doğa fotoğrafçılığı gibi olanaklara katılma imkanı bulabilmektedir (F.I.C.C., 2018: 5). Kamp bölgeleri veya karavanlar için park alanları ucuz turizm firsatı sunmasından dolayı, insanların tercihlerini bu turizm faaliyetine kaymasında etkili olabilmektedir.

Bir başka yönüyle kamp turizmi ele alınacak olursa; şehirleşme, nüfusun yaşlanması gibi değişimlerin yaşanması geleceğin kamp alanlarının değişiminde önemli rol olmaktadır. Yaşanan bu değişimler kamp alanı işletmecilerinin kararlarında belirleyici rol almasını sağlamaktadır (Milohnic ve Bonifacic, 2014: 370). İnsanların konaklama, ulaşım, yeme-içme gereksinimlerini kendileri çözme, farklı ülkeler gezip görmek ve genellikle daha uygun fiyata tatil yapmak amacıyla karavanları ve çadırları ile yaptıkları faaliyet kamping ve karavan turizmi olarak karşımıza çıkmaktadır (Kırklareli Kültür Turizm, 2018).

Bir bölgenin kamping alanı olarak ön plana çıkması için göz önünde bulundurulması gereken bazı kurallar vardır.Bu kurallara göz attığımızda; İdeal bir kamp yeri, açı alanda ve zemini yağmuru drene edilebilecek şekilde hafif eğimli, kamping alanında yaşayan insanların hayatını tehlikeye sokabilecek çı̆̆ ve heyelan riskinin yaşanmaması gereklidir. Bunun yanı sırabiyo-iklimsel konfor bakımından rakımı 800-2000 metre arasında olan, doğu ve güneye bakan, rüzgâr hızının çadırlara zarar verecek şekilde olmaması önemli hususlar olarak görülmektedir (Topay ve Koçan, 2009: 118).

\section{Ağrı İli Coğrafi Yapısı}

Ağr1 ili toplam sahip olduğu nüfus olarak incelendiğinde537.093, nüfus yönünden de Türkiye'deki iller arasında 39.sırada olduğu görülmektedir. Aritmetik nüfus yoğunluğu yönünden ele alındığında ise Türkiye'deki 81 il içerisinde 58. sırada yer almaktadır (TÜİK 2020). Ağrı ülkemizin hızlı göç veren illerinden birisi olarak karşımıza çıkmaktadır. Ağrı İli aynı zamanda kademeli göç olgusunun olduğu yerleşmelerden biridir. İl merkezi olan Ağrı Şehri ile ilçe merkezleri olan Doğubayazıt ve Patnos şehirleri, ilin kırsal kesiminden ve diğer ilçe merkezlerinden göç almaktadır. Bu kademeli göçün ana sebebi ise istihdam koşullarının yetersizliği ve işsizlik olduğu görülmektedir(Kaya vd., 2010: 18-19).

http://dergipark.gov.tr/aicusbed 6/2 Ekim/ October 2020 
Ağrı ilinin topraklarının \%46'sını dağlar, \%29'unu ovalar, \%18'ini platolar ve \%7'sini yaylalardan meydana gelmektedir. Ağrı ilinde, başta büyük Ağrı Dağı $5137 \mathrm{~m}$. yüksekliğiyle ve güneyinde ise $3896 \mathrm{~m}$. yüksekliğiyle Küçük Ağrı Dağı olmak üzere yükseklikleri 3.000 m. aşan birçok doruktan meydana geldiği görülmektedir. Diğer dağlar ise Tendürek 3.343 m. yükseklikte, 4.058 m. Yüksekliğiyle Süphan ve Hama Dağı, 3279 m. yükseklik ile Aşağ1 Dağ, 3243 m. yüksekliği ile Karadağ ve 3250 m. yüksekliği ile Aladağ'dır (Yazgan ve Kanadalı, 2012:7).

\section{Ağrı İli Turizm Potansiyeli}

Ağrı ili, Orta Asya'dan gelen kavimlerin Anadolu'ya girişleri esnasında geçiş noktasında yer alması ayrıca birçok medeniyete ev sahipliği yapmış olmasından dolayı zengin bir kültürel mirasa sahiptir (T.C. Serhat Kalkınma Ajans1, 2013: 66). TRA2 Düzey Bölgesi’nde (Ağrı, Ardahan, Iğdır, Kars) yer alan Ağrı, bölgenin İpek Yolu gibi önemli ve stratejik özellikleri olan bir ticaret güzergâhı ile birlikte Kafkaslardan Anadolu'ya geçiş yolu üzerinde yer almaktadır. Kervan yollarının bölgede birleşmesinden dolayı bölgeye hareketlilik ve medeniyetin gelmesine neden olmuştur (Çalışkan, 2014: 11).Tarihsel süreçte geçiş noktasında yer alan Ağrı, günümüze ulaşan höyükler, kale kalıntıları, oyulmuş mağaralar, mahzenler, yer altı tünelleri, kervan yolları, taş ve kayalara işlenmiş kitabeler, yer altından çıkarılan belgeler, eski kültür ve medeniyetlerden kalan zengin biraz olarak karşımıza çıkmaktadır (T.C. Ağrı Valiliği Çevre ve Şehircilik İl Müdürlüğü, 2011: 15).

Ağrı ili turizm potansiyeli yönünden yüksek bir değere sahip bir ildir. Fakat buna rağmen bu potansiyel geçmişten günümüze yeterince değerlendirilemediği görülmektedir. Sosyo-ekonomik gelişmişlik düzeyleri incelendiğinde en az gelişmiş bölgeler arasında yer almaktadır. Bunun sonucunda bazı sorunlar ortaya çıkmaktadır. İlde işsizlik, emeksermaye,beyin göçü, bölgede göç almanın getirdiği sosyal problemler, kaynakların atıl kalması gibi sorunlarla karşı karşıya kalınmaktadır. Bu yüzden il ve çevresinde kapsamlı bir bölgesel kalkınma programına ihtiyaç duyulmaktadır. Bu programın sanayiye destek verecek şekilde ticaret, tarım, turizm ve hizmetler sektörünü de geliştirmesi şarttır (Karabulut ve Oral, 2010: 259).

Son yıllarda bölgede turizm potansiyelinin değerlendirilmesine yönelik birçok çalışma yer almaktadır. Bunlar; Doğa Turizmi Master Planı, Dap Planı, 2023 Turizm Vizyonu çerçevesince kamu 2010-2013 TRA2 Bölge Planı gibi planlar olarak karşımıza çıkmaktadır. Ekonomik, sosyal, kültürel ve çevresel yönden etkilerinin gözlemlendiği turizm sektörünün, Ağrı açısından

http://dergipark.gov.tr/aicusbed 6/2Ekim /October 2020 
ekonomik ve sosyal kalkınmada önemli bir rol üstlenerek hem il ekonomisine hem de ülke ekonomisine olumlu katkıları olacağı öngörülmektedir.

Ülkemiz flora (bitki) ve fauna (hayvan) zenginliği bakımından dünyada kıta özelliği gösteren ender ülkeler konumunda yer almaktadır (Bozok ve Yılmaz, 2008: 125). Ağrı ili ve çevresi de bu yönüyle değerlendirildiğinde hem jeolojik oluşumları hem de biyoçeşitlilik açısından günümüzün yükselen ekonomisi olan turizm yönünden önem arz etmektedir. Bölgede doğa turizmi, tarih ve kültür değerleri yanında gün geçtikçe farklı bir ivme kazanmaktadır. Bölge doğal yapısı ve habitat özellikleri bakımından özel bir konumda yer almaktadır. Doğubayazıt Sazlığı, Balık Gölü ve Murat Çayı ender bulunan kuş türlerin yanı sıra aynı zamanda birçok yaban hayvanın barındığı alanlardır (Adızelvd., 2011: 628).

$\mathrm{Bu}$ yörede yüksek dağ göllerinde ve soğuk sularda yaşayabilen alabalıklar dünyanın çok nadir yerinde bulunabilecek kalitede olduğu görülmektedir. Doğubayazıt Sazlığı da yöreye önemli bir biyoçeşitlilik sunmaktadır. Başta kuşlar olmak üzere birçok yaban hayvanına ev sahipliği yapmaktadır. Boz ayı, kurt, yabandomuzu ve tilki sazlıkta sıkça görülen canlılardır (Adızel vd., 2011: 630). Bölgede bir Türkiye endemiği olan Bendimahi kertenkelesi ve nesli tehlikede olan Himalaya mavi kelebeği bulunmaktadır(www.turkiyesulakalanlari.com). Doğubayazıt İlçesi ile Ağrı Dağı arasındaki, Şeyhli ve Gölyüzü arasında bir konumda bulunan Sazoba köyündeki bataklık alandan oluşan bölge ülkemizin önemli 100 kuş türünün barınma sahası olarak bilinmektedir. Bu sazlık alan, Balık Gölü’nden ve Tendürek Dağı'ndan gelen derelerle beslenir. Yörede bulunan yaygın kuş türleri ise şunlardır; erguvani, çayır delicesi, boz ördek, pasbaş, patka, turna, kızılgaga ve kızılbacak olarak başlıcaları sayılabilir (Yıldırım, 2014: 154). 
Tablo 1. Ağrı İlindeki Potansiyel Turistik Alanlar:

\begin{tabular}{|c|c|c|}
\hline $\begin{array}{l}\text { TURIZMM } \\
\text { TÜRLERİ }\end{array}$ & İlçeler & AĞRI İLİNDEKİ TURIZM POTANSIYYELİ \\
\hline \multirow{8}{*}{$\begin{array}{l}\text { Kültür ve Tarih } \\
\text { Turizmi }\end{array}$} & Merkez & $\begin{array}{l}\text { Harabe göl ve Pazı Kaleleri, Suçatağı Yerleşimi, } \\
\text { Yığıntepe Höyüğg̈u }\end{array}$ \\
\hline & Doğubayazıt & $\begin{array}{l}\text { İshak Paşa Sarayı, Doğubayazıt Kalesi, Beyazıt Eski } \\
\text { Camii, Kızıl Ziyaret, Gürgüre, Ardıç ve Balıklı göl } \\
\text { Kaleleri, Ferhat Su Kanalı, Pınarcık Kalesi ve } \\
\text { Nekropolü, Şorik Kalesi ve Nekropolü, Alacalı } \\
\text { Köprüsü }\end{array}$ \\
\hline & Eleşkirt & $\begin{array}{l}\text { Toprakkale Antik Kenti, Toprakkale Camii, Sadaklı } \\
\text { Köyü Höyü̈̆ü, Pirabat Höyüğ̈̈ }\end{array}$ \\
\hline & Patnos & $\begin{array}{l}\text { Patnos Kümbetleri, Aznavur Tepe Höyügü ve Kalesi, } \\
\text { Girik Tepe, Esenbel (Meciya) Kalesi, Keçi/Kalebızın } \\
\text { Kalesi, Kuli/Kalekuli Kalesi, Liç Kalesi ve } \\
\text { Nekropolü, Dedeli Köyü Kalesi ve Nekropolü, } \\
\text { Konakbey ve GavurdağıNekropolü, Köseler Köyü } \\
\text { Kümbeti, Bağdişan Höyüğüu }\end{array}$ \\
\hline & Diyadin & $\begin{array}{l}\text { Diyadin, Tokluca, Avnik ve Kuje Kaleleri, Meya } \\
\text { Antik Kenti, Dedebulak Köyü Kalesi ve Nekropolü, } \\
\text { Heybeliyurt Kalesi ve Nekropolü, Büvetli Köyü ve } \\
\text { Nekropolü, Yeşildurak Köyü Höyüğü }\end{array}$ \\
\hline & Tutak & $\begin{array}{l}\text { Karagöz Kilisesi, Kan, Zincir, Çırpılı Köyü Kaleleri, } \\
\text { Atabindi Köyü Kaya Mezarları ve Kaya Yerleşimi, } \\
\text { Atabindi Köprüsü }\end{array}$ \\
\hline & Hamur & $\begin{array}{l}\text { Şoşik, Haveran ve Karlıca Kız Kaleleri, Hamur } \\
\text { Kümbetleri, Gültepe Höyüğü, Yamaç Mezrası } \\
\text { Höyüğü, Beklemez Köyü Kardeşler Mezrası Kaya } \\
\text { Yerleşimi ve Kaya Mezarları }\end{array}$ \\
\hline & Taşlıçay & $\begin{array}{l}\text { Gündoğdu Köyü Mağara Mezrası ve Kaya Mezarları, } \\
\text { Dumanlı Köyü Kaya Yerleşimleri ve Kaya Mezarları, } \\
\text { Akyıldız Köyü Nekropolü, Taşlıçay Höyüğü, Yassı } \\
\text { Höyük }\end{array}$ \\
\hline \multirow{4}{*}{ İnanç Turizmi } & Doğubayazıt & $\begin{array}{l}\text { Ahmed-i Hani Türbesi, Nuh'un Gemisi'nin izi, } \\
\text { Seslitaş Köyü Mezarlığ1, Seslitaş Kurganı }\end{array}$ \\
\hline & Patnos & Patnos Kümbetleri \\
\hline & Hamur & Sürmeli Mehmet Paşa Kümbeti \\
\hline & Eleșkirt & Toprakkale Camii \\
\hline
\end{tabular}

http://dergipark.gov.tr/aicusbed 6/2Ekim/October 2020 


\begin{tabular}{|c|c|c|}
\hline & Tutak & Karagöz Kilisesi, İsaabat Köyü Kilisesi Kalıntısı \\
\hline & Taşlıçay & Üçkilise \\
\hline & Doğubayazıt & Buz Mağarası \\
\hline & Patnos & Hesar Mağarası \\
\hline & Diyadin & Meya Mağaraları \\
\hline & Taşlıçay & Sinek ve Aladağ Yaylaları \\
\hline & Eleşkirt & Davul Yaylası \\
\hline & Patnos & Pani Yaylası, Katavin Yaylası \\
\hline & Doğubayazit & $\begin{array}{l}\text { Hz.Nuh’un Gemisi kalıntısı, Meteor Çukuru, Büyük } \\
\text { ve Küçük Ağrı Dağı, Balık Gölü, Gülyüzü ve Saz } \\
\text { Göl, Krater Gölü (Tendürek Dağı üzerinde), Buz } \\
\text { mağarası, Keşişin Bahçesi, İpek Geçidi (İpek Yolu), } \\
\text { Doğubayazıt Sazlıkları }\end{array}$ \\
\hline & Diyadin & $\begin{array}{l}\text { Tendürek Dağı, Murat Kanyonu, } \\
\text { travertenleri ve traverten köprüleri }\end{array}$ \\
\hline & Eleşkirt & Köse Dağ1 \\
\hline & Hamur & Aladağlar \\
\hline & Eleşkirt & Güneykaya Kayak Tesisleri \\
\hline Kış Turizmi & Merkez & Budi Kayak Merkezi, Küpkıran Kayak Tesisleri \\
\hline & Diyadin & Diyadin Kaplıcalar Bölgesi, Köprü Kaplıcası \\
\hline $\begin{array}{ll}\text { ve } & \text { Sağlık } \\
\text { Turizmi } & \end{array}$ & Merkez & Dambat Çermiği ve Maden Suyu \\
\hline & Doğubayazıt & Doğubayazıt Sazlıkları \\
\hline (Ornitoturizm) & Patnos & Sarısu Ovası Sulak Alanları \\
\hline
\end{tabular}

Kaynak: Karabulut, K. ve Köksal, Y. (2018). "Ağrı İlinin Turizm Potansiyeli ve Turizmi Geliştirmeye Yönelik Çözüm Önerileri”. (Ed. K. Karabulut) Ağrı ilinin sosyo-ekonomik Profili. Ankara: Salmat Basım Yay. 205-227. 


\section{Balık Gölünün Turizm Açısından Değerlendirilmesi}

Doğubayazıt ilçe merkezinin kuzeybatı taraflarında yer alan Balık Gölü Doğubayazıt ilçe merkezine $54 \mathrm{~km}$ uzaklıkta olup, Taşlıçay ilçe merkezine ise $27 \mathrm{~km}$ uzaklıkta bir konumda yer almaktadır. Yüksek dağlar tarafindan çevrelenen bir çöküntü alanı içerisinde kuzey-güney doğrultusunda uzanan ve deniz seviyesinden yaklaşı $2250 \mathrm{~m}$. yükseklikte yer alan Balık Gölü tipik bir lav setti gölüdür. Balık gölü deniz seviyesinden yaklaşık 2.241 m yükseklikte yer alması sebebiyle, Türkiye'nin en yüksekte yer alan doğal gölü olma özelliğini barındırır.

Alanı $34 \mathrm{~km}^{2}$ olan gölün suları tatlıdır. Ortalama derinliği ise 70 metre civarında olup gölün en derin yeri 100 metredir. Gölün kuzey-güney yönündeki boyu 10000 metre olup, doğu-batı yönündeki eni ise 2500 ile 6250metreler arasında değişim göstermektedir. Balık gölünü en dar kesimini oluşturan orta kısmının uzunluğu ise 2000 metre olduğu görülmektedir. Gölün şekli incelendiğinde düzensiz olup, kenar çizgileri ise girinti ve çıkıntılı olmaktadır. Ülkemizdeki göller genellikle bir şehrin çekim alanında bulunması, turizm yörelerine ve deniz kıyılarına yakınlık-uzaklık durumuna veya orman içinde, dağlık alanlarda yer alması gibi özelliklerine göre coğrafi konumlarına göre turizme açılmaktadır. Turizme açılan göller incelendiğinde yakınındaki bir şehrin çekim alanına göre ulaşım kolaylığı olan göller olduğu görülmektedir. $\mathrm{Bu}$ ve benzeri göllerin günlük rekreasyon tesislerine (çay bahçesi, lokanta vb.)rekreasyona açılarak, konaklama tesisi yapılarak turizme açılmaktadır. Fakat Ağrı İlinde yer alan Balık Gölü ve Çevresi bugüne kadar turizme açılmadığı gibi coğrafi tanıtımı bile etkili bir şekilde yapılamamıştır ( Kaya, 2018: 25).

Balık gölü özellikle yükseklik yönünden ünlenmiş olması rağmen burasının yeterince gelişmemesinin sebebi öncellikle bir dönem ülkemizin özellikle Güney ve Doğu Anadolu bölgesini etkisi altına alan terör olaylarıdır. Çevresindeki birkaç ilin tek gölü olması sebebiyle böyle bir turizm potansiyeli hem il turizmine hem de ülke turizmine kazandırmak önemlidir. Bunu yapabilmek için ise öncellikle çok kötü olan yollarının yapılıp otel işletmecilerine çeşitli ayrıcalıklar sunularak buradaki turizm hareketliliği canlandırılmalıdır. Zira Balık Gölünde şuan da herhangi bir konaklama işletmesi bulunmamaktadır. 
Harita 1: Balık Gölü Haritası

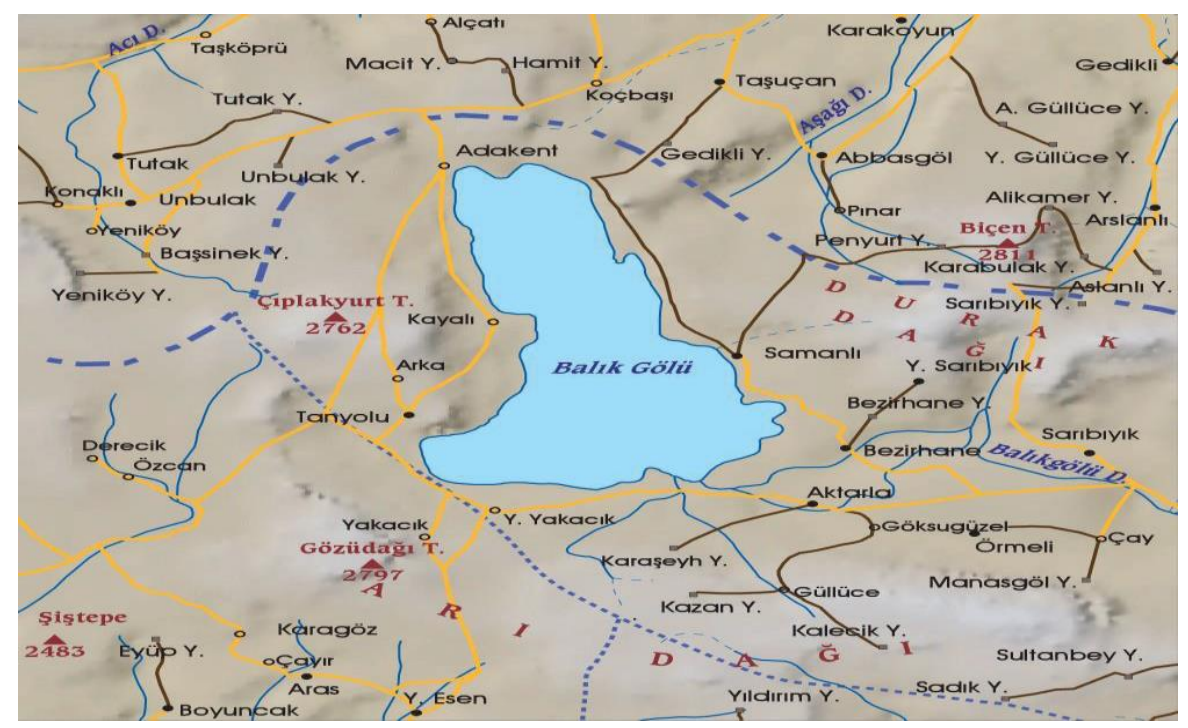

Kaynak: Türkiye Göller Atlası.

Balık gölü dünyada sadece bu gölde bulunan bir balık türüyle ünlüdür. Kırmızı benekli alabalığı ile ünlü olan bu gölümüzün suyu tatlıdır. Balık gölünde yetişen kırmızı benekli diğer adıyla kızıl alabalık doğal ortamda yetişmesi sebebiyle çok lezzetlidir.Soğuk kaynak sularıyla ve içilebilir derecede temiz sularıyla güzellik kazanan gölün etrafı ağaç bakımından ise oldukça kısır bir durumdadır. Doğu Anadolu'nun en güzel gölü olabilecek bir doğal güzelliğe sahip olmasına rağmen, bu imkân çeşitli sebeplerden dolayı yeterince değerlendirilememektedir. Göl çevresinde flora, alpin dağ çayırlardan oluşur. Özellikle ilkbahar ve yaz aylarında bu çayırlıklar rengârenk çiçeklerle bezenir ve çevre çok güzel bir doğal güzellik kazanır. Göl çevresi, dik yamaçlar ve tepelik alan ve kayaçlardan oluşmaktadır. Doğubayazıt Sazlığı; Doğubayazıt şehri ile Ağrı Dağı arasındaki, Şeyhli ve Gölyüzü gölleri arasında bulunan Saz oba köyündeki bataklık alanlardan oluşmaktadır. Bu sazlık da, ülkemizin önemli 100kuş türü barınma alanı arasında bulunmaktadır. Koruma statüsü olmayan ve yaklaşı olarak 1.000 ha'lık bir alandan oluşan sazlık 2.000 m yükseltisinde yer almaktadır. Sazlık alan, Balık Gölü'nden ve Tendürek dağından gelen dereler yoluyla beslenmektedir(Kaya, 2018: 26).

\section{Balık Gölü’nün İl Ekonomisine Etkisi}

Ağrı ilinin genel ekonomik yapısı incelendiğinde; ilin kalkınma programlarında ilk sırada bulunmaktadır. Bundan dolayı kişi başına 
hesaplanan milli gelir açısından son sıralarda yer almaktadır. İklim ve ulaşım şartlarının olumsuz olması sebebiyle yapılan sanayi yatırımlarını ve faaliyetlerini de olumsuz yönde etkilemektedir. Hali hazırda bulunan sanayi sektörleri tarım ve hayvancılık alanında yığıldığı görülmektedir. Sanayi yatırımlarının yeterli düzeyde olmaması ve aynı zamanda yapılan tarım sanayisinin gözle görülür seviye de gelir sağlamaması nedeniyle ekonomik ve ticari hayat, büyük çoğunlukla hayvancılık sektöründe birikmektedir. $\mathrm{Bu}$ yönüyle değerlendirildiğinde Ağrı ilimiz sanayileşme alanında zayıf bir durumda olup turizm, hayvancılık ve sınır ticareti alanında ise gelişmiş bir konuma sahiptir (Fakirullahoğlu, 2018: 229).

Turizm alanında özellikle değerli potansiyelleri olan Ağrı buradan elde edilecek ekonomik gelir yönünden çok düşük seviyelerde kalmaktadır. Özellikle konaklama sektörünün yeterince gelişmemesi sebebiyle buraya gelen turistler günübirlik veya daha kısa süreli seyahat yapmalarına neden olmaktadır. Bu da turizmden elde edilecek gelirin yeterli seviyeye ulaşmasına engel olmaktadır. Balık gölü de özellikle ulaşımın çok kötü olması konaklama ve restoranlara sahip olmaması nedeniyle il ekonomisine katkısını sınırlı düzey de kalmasına neden olmaktadır.

Tablo 2. Ağrı ili somut turizm varlıkları inceleme sonuçları:

\begin{tabular}{|l|c|c|c|}
\hline İNCELEME ALANI & $\begin{array}{l}\text { İÇSEL } \\
\text { DEĞER } \\
\text { ORTALAMASI }\end{array}$ & $\begin{array}{l}\text { KULLANIM DEGERì } \\
\text { ORTALAMASI }\end{array}$ & $\begin{array}{l}\text { GENEL } \\
\text { ORTALAMA }\end{array}$ \\
\hline Ağrı Dağ1 & 4,50 & 4,00 & 4,25 \\
\hline İshakpaşa Sarayı & 3,63 & 3,75 & 3,69 \\
\hline $\begin{array}{l}\text { İshakpaşa Sarayı Çevresindeki } \\
\text { Yapılar }\end{array}$ & 3,00 & 3,50 & 3,25 \\
\hline Nuh'un Gemisi & 3,88 & 2,13 & 3,00 \\
\hline Balık Gölü & 2,75 & 2,00 & 2,38 \\
\hline Diyadin Kaplıcaları & 2,00 & 2,75 & 2,38 \\
\hline Meteor Çukuru & 2,00 & 2,00 & 2,00 \\
\hline Kümbet & 2,00 & 2,00 & 2,00 \\
\hline Buz mağarası & 1,50 & 1,69 & 1,59 \\
\hline Meya Kaya Yerleşimi & 1,81 & 1,13 & 1,47 \\
\hline Patnos Baraj Gölü & 1,38 & 1,50 & 1,44 \\
\hline Şoşik Kalesi & 1,38 & 1,00 & 1,19 \\
\hline Anzavur Kalesi & 1,13 & 1,13 & 1,13 \\
\hline Karagöz Kaya Kilisesi & 1,00 & 1,00 & 1,00 \\
\hline
\end{tabular}

http://dergipark.gov.tr/aicusbed 6/2Ekim/October 2020 
Kaynak: T.C. Serhat Kalkınma Ajans1, Misafirin Gözünden TRA2 Turizmi

Turizm sektöründeki temel destek unsuru olan konaklama imkânları açısından incelendiğinde destek unsurlarının Ağrı ilinin yetersiz olduğu görülmektedir. Tablo 2 incelendiğinde Ağrı ilinin diğer turizm potansiyellerinde olduğu gibi Balık Gölünün de destek unsurlarının zayıf olduğu görülmektedir. Bunun en önemli sebebi ise göl çevresinde konaklama tesisinin bulunmamasından kaynaklanmaktadır.

\section{Balık Gölünde Turizmin Geliştirilmesi İçin Neler Yapılabilir?}

Balık gölü bu güne kadar turizmden hak ettiği değeri alamamıştır. Aslında Türkiye'nin en yüksek rakımında bulunması ve oksijen deposu olmasına rağmen bazı sorunlardan ve ilgisizlikten dolayı bu saklı cennet gün yüzüne çıkarılamamıştır. Hak ettiği değeri alamamasının en önemli sebebi maalesef balık gölünün ulaşım sorunun olmasıdır. Özellikle Ağrı merkeze çok uzak olmamasına rağmen yollarının kötü olması sebebiyle insanların gitmelerini olumsuz etkilemekte veya yolculuğun yorucu geçmesine neden olmaktadır. $\mathrm{Bu}$ yüzden balık gölünün turizm potansiyeli geliştirilmek isteniyorsa önce ulaşım sorunun giderilmesi gerekmektedir.

Daha sonra ise balık gölü çevresi ağaçlandırılmalıdır. Balık gölünde yükselti fazla olduğu için her ağaç ve bitki yetişmemektedir.1800 m yükseklikten itibaren, güneşten dünyamıza gelen 1 şı̆̆ı̀ $\% \quad 75$ 'ini kullanabilmekteyiz. Bu yüzden coğrafi enlem arttıkça güneşten gelen 1şı1k miktarının azalmasından dolayı bitkilerin 1şıktan yararlanma miktarı da oransal olarak düşüş göstermektedir. Özellikle bu yükselti de huş ağacı ve dış budak ağacı yetiştirilebilir. Sert iklime dayanıklı bir ağaç olması sebebiyle balık gölünde düşünülebilir.

Balık gölünde turizm potansiyeli geliştirilmek isteniyorsa bir diğer proje spor kamp merkezleri kurulabilir. Özellikle 2000 metre üstünde ki rakımlarda yapılan antrenmanlar sporcuya deniz seviyesinde yapılan antrenmana göre iki kat daha fazla etki yapmaktadır. O yüzden Balık Gölünün manzarası ve yükseltisi kullanılarak burada sporcu kamp sahaları ve sporcu kamp merkezleri kurulabilir. Ağustos ayında bile sıcaklığın düşük olması ayrıca sürekli yükselen kurlardan dolayı yurtiçinde ki futbol, basketbol vb. branşlardaki takımlarımız yurtdışına gitmesine gerek kalmadan balık gölünde kamplarını yapabilecek imkânları sağlayabiliriz. Otel işletmecilerine yer tahsisi yaparak ve 6. Teşvik Bölgesi'nin avantajları kullandırılarak balık gölüne otel ve spor kamp sahaları kurdurularak burasının turizm potansiyeli açığa çıkarılabilir.

http://dergipark.gov.tr/aicusbed 6/2 Ekim/ October 2020 


\section{Fotoğraf 1. Balık Gölü}

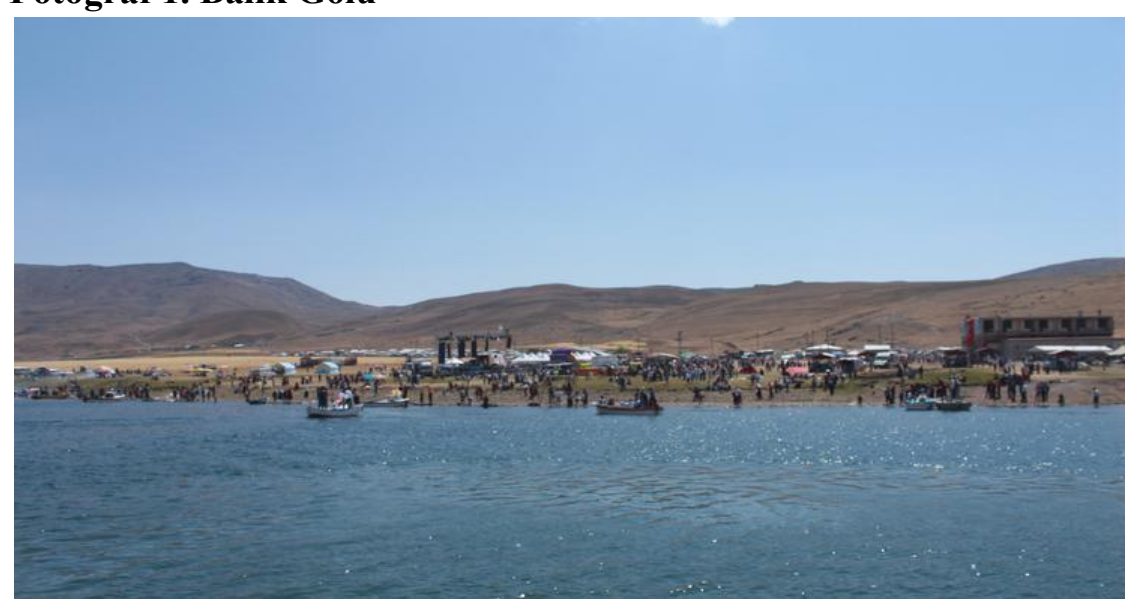

Kaynak: Balık Gölü’nde Taşlıçay Belediyesi tarafından "1. Balık Göl Festivali" gerçekleştirilmiştir (Fotoğrafta festivalden bir görüntü alınmıștır).

Balık gölünde turizm faaliyetlerini geliştirmek istiyorsak bir diğer yapılması gereken şey çadır kamp alanlarını geliştirme ve dağ evlerini inşa etme yoluyla gelen turist sayısını arttırmaktır. Özellikle son yıllarda ekonomik ve cazip olması sebebiyle çadır kampını tercih edenlerin sayısı hızla artış göstermektedir. $\mathrm{Bu}$ yüzden balık gölünde yapılacak çadır kamp alanları burasının tercih edilme oranını artıracaktır. Ayrıca etrafının dağlarla çevrili olması sebebiyle dağ evleri de yapılabilir. Hobbit filminden esinlenilerek ülkemizde de yavaş yavaş turizm için kullanılan hobbit evleri özellikle balık gölü için çok uygun konumdadır. Çünkü göl manzaralı olması sebebiyle Türkiye'de sayılı yerlerin başında yer almaktadır. Ayrıca; Balık Gölü, Türkiye'nin önemli kuş gözlem alanlarından biri olma özelliğine sahiptir. Yaban hayatı için önem arz eden göl çevresinde turistler için kuş gözlem kuleleri yapılabilir. 


\section{Fotoğraf 2. Balık Gölü}

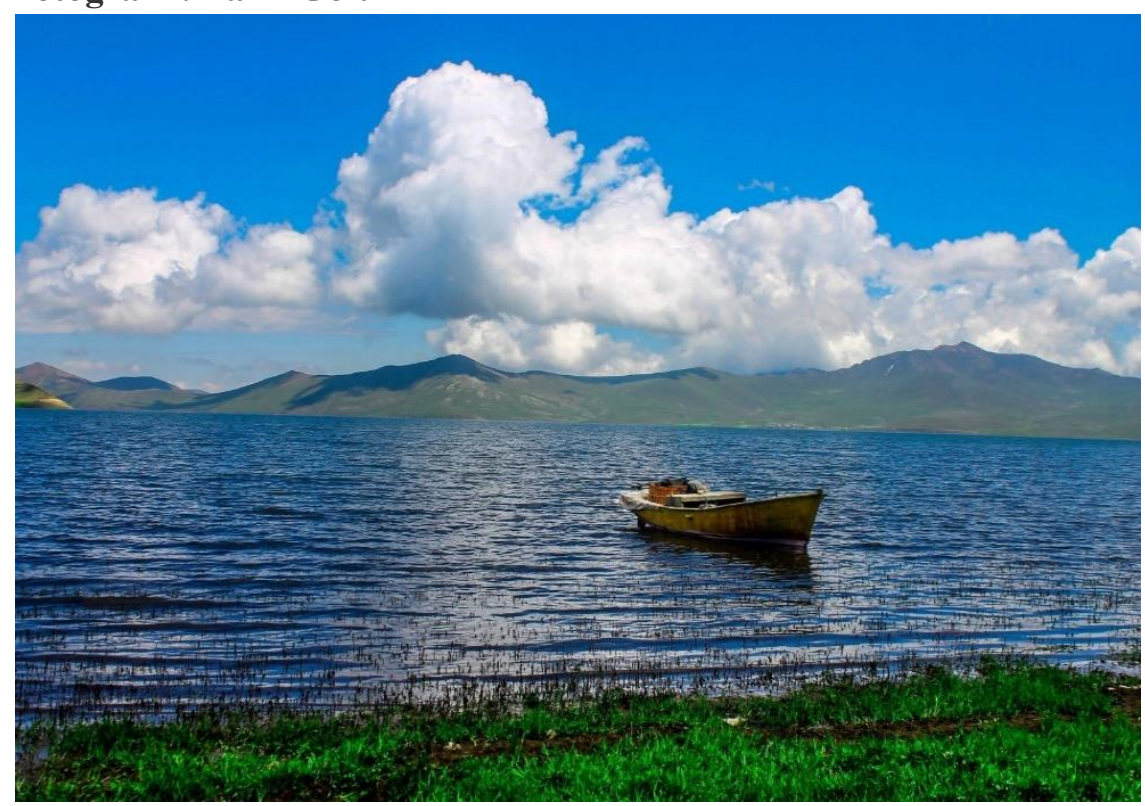

Fotoğrafta Balık Gölü’nden bir manzara görülmektedir.

\section{Sonuç ve Öneriler}

Balık Gölü ve çevresinde turizm faaliyetleri hali hazırda idealden çok uzak, kayıplarla dolu, plansız ve sürdürülebilir olmayan bir şekilde işlemekte ve bu işleyiş hala devam etmektedir. Bu yüzden Ağrı İli Turizm Havzası içerisinde öncelikli olarak Balık Gölü ve çevresinin öne çıkan potansiyellerinin belirlenmesi ve bu çerçevede Balık Gölü ve Çevresi Turizm Master Planı hazırlanması sürdürülebilir turizm açısından en gerçekçi başlangıç adımı olacaktır. İşin uzmanı profesyonel ekiplerce hazırlanacak böyle bir projenin zaman içerisinde sağlayacağı yeni gelişmeler ve açılımlarla birlikte, küçük ölçekli bir bölgesel kalkınma projesine dönüşmesi de mümkün olacaktır. Bölge ve yöre halkı için önemli olan bu Göl'ün yine çeşitli festivaller düzenlenerek iyi bir tanıtımının yapılması gereklidir.

Balık gölünün en önemli sorunu olan ulaşım sorunu çözüldüğü takdirde gelecek turist sayısında önemli düzeyde bir artış olacağı beklenilmektedir. Ulaşım sorunun çözülmesiyle birlikte özellikle İranlı turistlerin buralara daha fazla gelmesi söz konusu olacaktır. Çünkü İran'ın özellikle tatil yapma yönünden bazı sınırlamaları olması ayrıca eğlence kültürünün yasak olması dolayısıyla ülkemizi tercih etmektedirler. Ağrı ilinin de İran ile sınır bağlantısının olması ili avantajlı konuma getirmektedir. $\mathrm{Bu}$

http://dergipark.gov.tr/aicusbed 6/2 Ekim/ October 2020 
yönüyle değerlendirildiğinde balık gölünün ulaşım, konaklama ve tesisleşme sorunu çözülürse sadece ilimize değil ülke ekonomisine gerekli dövizin girişi sağlanmış olacaktır.

Balık Gölü dünyada sadece bu gölde yetişebilen kırmızı benekli balıkların koruma altına alınarak korunması sağlanmalıdır. Etkili tanıtım ve organizasyonlarla birlikte tesisleşme de sağlanırsa gastronomi yönünden de il ekonomisine katkı sağlayabilir. Özellikle burada kırmızı benekli balıkların koruma altına alınması gerekmektedir. Çünkü tadının çok lezzetli olması dolayısıyla gastronomi alanında değerlendirilebilecek bir potansiyele sahiptir. Yanlış ve bilinçsiz avlanmadan dolayı bitme noktasına gelmiştir. Bu yüzden alınacak önlerle birlikte kırmızı benekli balıkların korunması sağlanarak gastronomi turizmi yönünden değerlendirilebilir.

Ayrıca Balık Gölü konusunda bazı tehlikeler olduğu da söylenebilir. Ağrı'nın Doğubayazıt ilçesinin içme suyunun yaklaşık yüzde 80'i buradan temin edilmektedir. Bu konuda da yetkili kurumlar önlem almazsa 20 y1l sonra bu Göl küçücük bir göl haline gelebilir.

\section{Kaynakça}

Adızel, Ö.,Durmuş, A. ve Akın G. (2011). “Ağrı'nın Doğa Turizmi, Biyoturizm ve Ornitoturizm Potansiyeli' .III. Uluslararası A $\breve{g r l}$ Dă̆ ve Nuh'un Gemisi Sempozyumu, 12-14 Ekim 2010,Ağr1 İbrahim Çeçen Üniversitesi, 626-631, İstanbul.

Ağr1 Kültür ve Turizm Rehberi. (2011). (Haz. Bulut, E. M. ve Ayhan, N.) T.C. Ağrı Valiliği İl Kültür ve Turizm Müdürlüğü, Ağrı.

Barutçugil, İ. S. (1986). Turizm Ekonomisi ve Turizmin Türk Ekonomisindeki Yeri. İstanbul: Beta Yayınları.

Bozok, D. ve Y1lmaz, Ö. (2008). “ Eko-Turizm”, Turistik Ürün Çeşitlendirmesi, C. Avcıkurt ve N. Hacığlu (Ed.), Turistik Ürün Çeşitlendirmesi, 111-136, Ankara: Nobel Yayın.

Çalışkan, U. (2014). Sarıkamış Kayak Tesisleri ve Konaklama Hizmetleri Müşteri Memnuniyeti Destinasyonunda Sosyolojik Bir Çözümleme’’. International Journal of Human Sciences, 10(1), 780-794.

Doğan, S. Ö. (2011). Silivri'de turizmin gelişmesi: sorunlar ve çözüm önerileri. Doğu Coğrafya Dergisi, 16(5), 90.

Doğantan, E. (2014). Frigya Bölgesine Alternatif Konaklama Tesisi Önerisi: Karavancılık. Anadolu Üniversitesi Sosyal Bilimler Enstitüsü, Yayınlanmamış Yüksek Lisans Tezi, Eskişehir. 
Fakirullahoğlu, Zeynep (2018). “Ağrı İli Sosyo-Ekonomik Profilinin Vergiler Açısından İncelenmesi: 2005-2016 Yılları Arasındaki Vergilerin Değerlendirilmesi”. Ağrı İlinin Sosyo-Ekonomik Profili.(Ed. Kerem Karabulut)Ankara: Salmat Basım Yay. 229-236.

Güzel, F. Ö. (2013). “Sosyo- Kültürel Açıdan Paradoks Yaratıcı Bir Sektör Olarak Turizm: Dalyan Hacioğlu (Ed.), Turistik Ürün Çeşitlendirmesi, 111-136, Ankara: Nobel Yayın. Harman Yayıncılık.

Her Mevsim Karadeniz Projesi Master Plan1, Trabzon Ticaret ve Sanayi Odas1, Harman Yayınc1lık, 2013.

Karabulut, K. ve Oral, İ. O. (2011). “Ağrı İlinin Sosyo-Ekonomik Yapısının Analizi”, (Editör: O.Belli) III. Uluslararası Ağrı Dağı ve Nuh'un Gemisi Sempozyumu, 12-14 Ekim 2010. Ağrı İbrahim Çeçen Üniversitesi, 259-272, İstanbul.

Kaya, F. (2018). “Ağrı İlinin Coğrafi Analizi”. (Ed. K. Karabulut) Ağrı ilinin sosyo-ekonomik Profili. Ankara: Salmat Basım Yay.1-32.

Kaya, F. (2016). “Ağrı Dă̆ı'nın Turizm Potansiyeli ve Değerlendirme Durumu'.Marmara Coğrafya Dergisi/ Marmara Geographical Review, Say1: 34, 217-229.

Karabulut, K. ve Köksal, Y. (2018). “Ağr1 İlinin Turizm Potansiyeli Ve Turizmi Geliştirmeye YönelikÇözüm Önerileri”. (Ed. K. Karabulut) Ağrı ilinin sosyo-ekonomik Profili. Ankara: Salmat Basım Yay. 205227.

Kurt Konakoğlu, S. S. (2018). Katılımcı Turizm Planlaması Yaklaşımı ile Amasya Kent Örneğinde Mekânsal ve Senaryo Analizi, Yayınlanmamış Doktora Tezi, Karadeniz Teknik Üniversitesi Fen Bilimleri Enstitüsü, Trabzon.

Milohnic, I. ve Bonifacic, J. C. (2014). Global Trends Affecting Camping Tourism; Manageria 1Challangesand Solutions. Toursimand HospitalityManagment 2014, (s. 380-393).

Somuncu, M. (2004). Dağcılık ve dağ turizmindeki ikilem: Ekonomik yarar ve ekolojik bedel. Coğrafi Bilimler Dergisi, 2(1), 1-21.

T.C. Ağrı Valiliği Çevre ve Şehircilik İl Müdürlüğü, 2011.

T.C. Serhat Kalkınma Ajansı 2012, Ağrı Doğa Turizm Master Planı 2013, Ağrı İl'inin Turizm Potansiyeli 2014.

Topay, M. ve Koçan, N. (2009). Kamping/Çadırlı Kamp İçin Alan Kriterlerinin Belirlenmesi ve Bartın-Uluyayla'da Örnek Bir Uygulama. Süleyman Demirel Üniversitesi Orman Fakültesi Dergisi(1), 116-128. 
Usta, Ö. (2016). Turizm Genel ve Yapısal Yaklaşım, Ankara: Detay Yayınc1l1k.

Yazgan, Ş, Kadanalı, E . (2012). Ağrı İlinin Kırsal Turizm Potansiyelinin Değerlendirilmesi. Karamanoğlu Mehmetbey Üniversitesi Sosyal Ve Ekonomik Araştırmalar Dergisi, 2012 (1) , 5-10.

Yıldırım, K. (2014). “Nuh’un Şehri: Güneşi Kucaklayan Ağrı”, Ağrı İli’nin Turizm Potansiyeli, Ağrı İbrahim Çeçen Üniversitesi 1. Araştırma Proje Yarışması, 9-281, Ağrı İbrahim Çeçen Üniversitesi Yayınları.

http://www.turkiyesulakalanlari.com/dogubayazit-sazliklari-agri. Erişim tarihi: 23.03.2020.

Kırklareli Kültür Turizm (2018).http://www.kirklarelikulturturizm.gov.tr Erişim Tarihi: 14.03 .2020 